\title{
Comparing the labour market position of Poles and Bulgarians before and after migration to the Netherlands
}

Marcel Lubbers ${ }^{1 *}$ and Mérove Gijsberts ${ }^{2}$

\author{
* Correspondence: \\ M.Lubbers@maw.ru.nl \\ ${ }^{1}$ Department of Sociology, Radboud \\ University Nijmegen, $6500 \mathrm{HE}$ \\ Nijmegen, The Netherlands \\ Full list of author information is \\ available at the end of the article
}

\begin{abstract}
This article compares the pre- and post-migration labour market position of recent migrants to the Netherlands from Poland and Bulgaria. Previously it has been hypothesized that migrants loose job-status due to migration when the pre- and post-migration jobs are compared, foremost supported with data from countries outside Europe. In this contribution we test the first part of the so-called U-curve hypothesis in the European context, testing the hypothesis for mobile EU migrants in a high skilled economy. Relying on data collected among new migrants from Poland and Bulgaria to the Netherlands we find that the socioeconomic status of the job in the Netherlands is lower in both migrant groups than the status of their last job in the country of origin, irrespective of the difference between the groups for a need of a work permit. This loss applies less for family-motivated migrants. Despite decline of job status, a higher proportion of migrants is more satisfied with the income that is generated from the job in the Netherlands than with the income generated in the job in the country of origin.
\end{abstract}

Keywords: Labour market integration, East European migration

\section{Introduction}

Migration is often associated with occupational downgrading. For Australia, Chiswick, Lee, and Miller (2005) and Mahuteau and Junankar (2008) found such a pattern of downgrading, as did Akresh (2006; 2008) for the US. For European countries, Simon, Ramos and Sanroma show for Spain in their Institute for the Study of Labor discussion paper that the downgrading hypothesis could be supported (2011), for migrants from different origins, including those who were free to move from Eastern Europe. In Germany, Bauer and Zimmermann (1999) published the Institute for the Study of Labor paper on ethnic German migrants' downward labour market mobility in the 1990s.

In this contribution we focus on the large east to west European migration flow as well and question the consequences of migration for the labour market position, with a focal point on Poles and Bulgarians who migrated to the Netherlands, a high skilled economy. Different from the migrants in the Anglo-Saxon studies, Polish migrants have been free to come to the Netherlands to live and work since 2004, though between 2004 and 2007 they needed a work permit in order to take up paid employment in the Netherlands. Here we compare the free to move and work Polish migrants

(c) The Author(s). 2016 Open Access This article is distributed under the terms of the Creative Commons Attribution 4.0 International License (http://creativecommons.org/licenses/by/4.0/), which permits unrestricted use, distribution, and reproduction in any medium, provided you give appropriate credit to the original author(s) and the source, provide a link to the Creative Commons license, and indicate if changes were made. 
to the Bulgarian migrants who registered as inhabitant of the Netherlands in 2010. Bulgarians are free to move since 2007 but for whom the work permit requirement applied until 1 January 2014. A Dutch employer wishing to take on a Bulgarian foreign worker had to apply for the work permit and had to provide evidence that he or she had first spent at least five weeks looking for candidates to fill the vacancy for which a work permit is not required (Rijksoverheid, 2013).

It is well established in the literature on migration that the economic outlook in the country of origin is a relevant push factor for migrants, while the economic outlook in the destination country is an important pull factor (Borjas, 1989; Castles \& Miller, 2003). Although this economic approach takes insufficient account of factors such as chain migration, it does provide an indication of the crucial role played by the labour market in understanding international migration processes. Different than in earlier studies, a focus on intra-EU mobile workers may provide evidence for labour market dynamics specific for the political-institutional context, since the investments for movement seem lower and the ease for return is higher (Engbersen, Ilies, Leerkes, Snel, \& Van der Mei, 2011). And also different from the study on Spain (Simon, Ramos, \& Sanroma, 2011), Bulgarian (and earlier also the Polish) migrants to the Netherlands faced an initial period of labour market restrictions by the work permit. Our aim in this study is to investigate to what extent in this specific political-institutional context, the labour market position of recently migrated Poles and Bulgarians in the Netherlands differs from their position in their country of origin.

In this study we question to what extent Polish and Bulgarian migrants have a job before and after migrating to the Netherlands, to what extent the socioeconomic status of their jobs changes as a result of migration and what differences there are between new migrants from Poland and Bulgaria. This builds on research on the economic integration of migrants (Chiswick et al., 2005) which postulates that migrants give up a job in their country of origin in order to take a job with lower status but higher income in the host country, driven by the motive that wages in the - wealthier - host country are substantially higher. Therefore we also address to what extent migrants have become more satisfied with their earnings when they compare the post-migration job to their pre-migration job.

Just like in other west and south European countries, migration by Poles and Bulgarians to the Netherlands has risen sharply since the accession of these two countries to the EU in 2004 and 2007, respectively (see Fig. 1). Poles have been for a decade annually the largest migrant group to the Netherlands. Bulgarians are among the top 10 largest migrant groups and outnumber other Eastern-European migrant groups. The economic crisis in Bulgaria was deeper than in the Netherlands in 2009 in terms of the decline of gross domestic product, whereas the Polish economy actually grew. The unemployment rate in both countries was however more than twice as high as in the Netherlands (Eurostat, 2013a). Our study focuses on Polish and Bulgarian migrants who registered as new residents of the Netherlands in 2009 and 2010. Migrants who had been entered in the Municipal Personal Records Database (GBA) were asked in late 2010 or early 2011 to take part in the 'Social and Cultural Integration Processes' survey (SCIP), on which this study is based. 


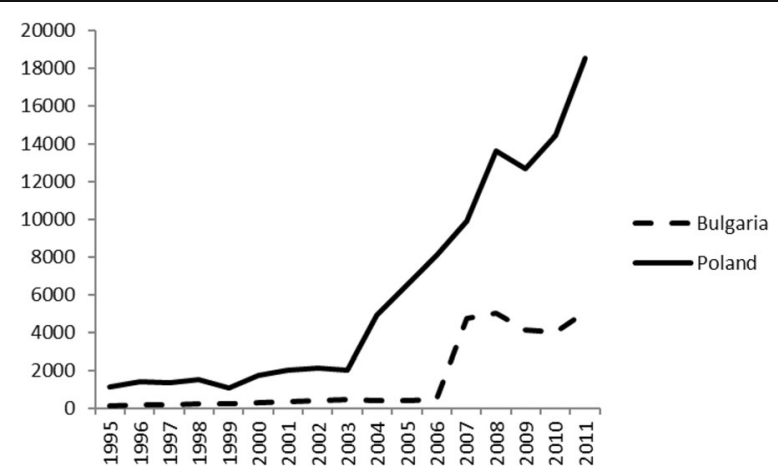

Fig. 1 Number of Polish and Bulgarian migrants entering the Netherlands each year whose country of origin is also their country of birth

\section{Expectations}

Following labour market theory in an immigrant context, we expect to replicate findings that supported three central hypotheses:

1) That migrants with an economic motive for migration have more often a job after migration than they had before migration (Borjas, 1989; Castles \& Miller, 2003);

2) That the job after migration has a lower occupational status than the job migrants had before migration, known as the first part of the U-curve hypothesis from Chiswick et al. (2005) and;

3) That satisfaction with income from the job after migration is higher than satisfaction with the job before migration (Baker \& Benjamin, 1994; Kennan \& Walker, 2011). We anticipate these hypotheses to hold for the Poles and Bulgarians to the Netherlands as well. However, since east-Europeans are more mobile in their movement within the EU than the migrants in the Anglo-Saxon countries studied, we derive additional hypotheses that account for the specific situation of the studied migrants in the Dutch context.

\section{Being employed}

During our study, Polish migrants were free to move to the Netherlands and to work on the Dutch labour market, without the need of a work permit. This strongly contrasts the strict migration policies that apply to migrants moving to the Anglo-Saxon migration countries. The European Union stimulates free movement of people and labour within its borders, creating the opportunity to easily move from one country to another. Moreover, as shown in the work from Engbersen, Leerkes, Grabowska-Lusinska, Snel, and Burgers (2013), a more diffuse pattern of migration follows from the institutional context of the European Union, with a large share of circulating migration, where migrants move back and forth between the country of origin and a country where work can be found. Our study is based on migrants who registered in the Netherlands. Migrants who stay more than four months in the country need to register in the municipality registration, even though there was no formal sanction on not doing it. Studies from Engbersen et al. (2013) and Van der Heijden, Cruyff, and Van Gils (2013) showed large rated of East European migrants that had not registered. In 2014, the Dutch government therefore started a pilot in some municipalities to require registration before migrants can take up work. At the time of our study, temporary migrants could register at the employees registration. We anticipate 
that economic migrants who are so mobile on the European labour market are likely to register only once they have an outlook for a more stable job position. We therefore expect that registered Polish migrants more often have a job in the Netherlands than before migration in Poland. As Bulgarians wishing to work in the Netherlands required a work permit in the time of our study, it would be straightforward to expect that Bulgarians in particular more often had a job in the Netherlands than they had in Bulgaria, and therefore even more so than Poles. However, descriptive research by a number of authors, including Engbersen et al. (2011) contradicts this. A more likely scenario is that many Bulgarians come to the Netherlands in the hope of finding work, but this is made more difficult by the work permit requirement, stimulating Bulgarians to find informal work. We therefore expect that Bulgarians less often have a (formal) job in the Netherlands as compared with having a job in the country of origin than Poles.

\section{Occupational downgrading}

Chiswick et al. (2005) present a U-shaped model in their study of labour market integration of migrants. According to this model, migrants shortly after migration experience downward mobility between the status of their last job before migrating and their job after migration. The authors posit that the main reason for this loss of status lies in the imperfect match between the human capital acquired by migrants in their country of origin and the skills required (e.g. qualifications and language skills) on the labour market in the destination country - a labour market with which migrants are moreover not yet sufficiently familiar. On the other hand, if migrants invest in capital that is specific to the destination country, their occupational status will rise and they will be able to regain the status they had in their country of origin immediately prior to migration. According to Chiswick et al. (2005) this U-curve is most pronounced among the highest-skilled migrants. Theoretically this is explained by the more difficult transferability of higher level diplomas from the country of origin to the country of migration labour market. Empirically, this could also be explained by ceiling effects, that this group has the greatest propensity to lose occupational status but also have the greatest potential to go on to achieve a high occupational level. The findings of Chiswick et al. (2005) about the general pattern of downgrading are replicated by Akresh (2006; 2008) and by Simon et al. (2011) in their discussion paper on Spain. These authors found that the occupational status before migration was higher than the first job after migration, and that after a certain period had elapsed the occupational status was higher than the first post-migration job. This U-curve is not always found, however. In another Spanish study, Amuedo-Dorantes and De la Rica (2006), argue that the occupational status of recent migrants from other countries in Europe, including Eastern Europe, is no lower than the occupational status of native Spaniards with comparable human capital, though that is the case for African migrants. However, this study did not compare occupational status before migration with occupational status post-migration. The same applies for a study of Polish migrants to Ireland (Barrett \& Duffy, 2008), which investigated the upward movement of the U-curve based on length of residence. Earlier cross-national research by van Tubergen $(2005 ; 2006)$ had already confirmed the upward movement of the U-curve, though this only applied for migrants who had been resident in the host country for at least ten years. The studies by Barrett and Duffy, and Van Tubergen contain no information on the pre-migration occupation, nor does the interesting study from Fuller and Martin (2012) for the Canadian situation where they predict immigrant employment 
sequences (and not the occupational status) in the first years of settlement. In fact this applies for much of the available research, with the exceptions of the studies by Chiswick et al. (2005), Mahuteau and Junankar (2008), Akresh (2008) and Simon et al. (2011). These studies provide evidence for downgrading of migrants in their jobs after migration. Since the Netherlands is a high-skilled economy we anticipate that migrants in general will lose occupational status in this country after migration. But for the most mobile migrants, the Poles in our study, we anticipate that those with a more temporary perspective to stay, the occupational status decline will be sharper. This expectation follows the argumentation about differences between economic and family motivated migration. Chiswick et al. (2005) posit that it is mainly migrants with economic motives who will see their occupational status decline. The underlying notion is that migrants who migrate for economic reasons do so primarily in order to generate more income and that they are therefore willing to take a job below the status of the job they had before migrating, provided the income they earn from it is higher than in the country of origin. The extra income can then be sent back to family in the country of origin. Following the line of reasoning used by Akresh (2006), family migrants will have more access to knowledge about the Dutch labour market because they will move in with somebody who already lives in the Netherlands. This should theoretically make it easier for them to find a job with an appropriate status. However, we like to argue that it is not only about information access that these migrants can and will spend more time looking for a job at the right level and that there will be less urgency to take a job only because of the income it provides. The labour participation rate of family migrants will then probably be lower, but the occupational status of those who are in work will be higher than that of labour migrants. The same logic may hold for differences between migrants with a temporary intention to stay versus those with a longer intention to stay. We therefore formulate the additional hypotheses that migrants who move to the Netherlands for economic reasons will see their occupational status fall more sharply than migrants who migrate to the Netherlands for family motives and that occupational status falls more sharply for migrants with a temporary stay perspective than among those with a longer stay perspective.

For the Bulgarians, with the need for a work permit at time of the study, we anticipate that the chances will be larger that they have difficulties finding a job in the Netherlands. Therefore, as was found by Engbersen et al. (2011), we anticipate them to work more often in the informal sector characterized by low status jobs as housekeepers, cleaners and waiters. Our hypothesis is that the socioeconomic occupational status of Bulgarians falls sharper after migration than that of Poles.

\section{Satisfaction with income}

A good deal of earlier research on the labour market situation of migrants has looked at the income generated by migrants. Migrants' income in the destination country was found to be lower than that of natives with comparable human capital (Baker \& Benjamin, 1994). Expectations regarding income improvement are a crucial element in the decision to migrate (Kennan \& Walker, 2011). However, we have no information about the income that migrants received in their most recent job prior to migration, though they were asked how satisfied they were with their income before and after migration. With a gross domestic product of 3,500 Euros per capita in 2009, Bulgaria can be described as one of the poorest countries in Europe. Polish GDP in 2009 was more than twice as high (7,800 Euros), though was still four times lower than in the 
Netherlands (32,800 Euros). A comparable picture emerges if we look at differences in average net income between the three countries. The average net income of employees in the Netherlands in 2010 was 23,674 Euros; average net income in Poland was less than a quarter of this (5,449 Euros) and in Bulgaria it was six times lower (3,735 Euros per annum) (Eurostat, 2013a; 2013b). We hypothesise that, because wages in Bulgaria are so low, Bulgarians experience a bigger rise in satisfaction with their income from employment before and after migration than Polish migrants.

\section{Data sources}

We employ data from the Dutch dataset 'Early Socio-Cultural Integration Processes among recent immigrants to Europe' (SCIP) (Diehl et al. 2015; Gresser \& Schacht, 2015, also for the questionnaire and methods report). In September 2010 a sample was drawn by Statistics Netherlands (CBS) among migrants aged between 18 and 65 years who had been entered in the Municipal Personal Records Database (GBA) of their municipality of residence for between September 2009 and September 2010 and who originated from Bulgaria or Poland and who held the nationality of the respective country of origin. Only municipalities which had received at least 25 migrants from a particular group were selected. For Polish migrants, who are fairly widespread across the Netherlands, a selection was then made from the 38 Dutch municipalities in which the largest numbers of Poles have settled.

Migrants were sent an invitation letter and, from November 2010, were approached face-to-face and invited to participate in a Computer Assisted Personal Interview (CAPIinterview). The interviewer was of the same origin group as the target respondent. The interviews were held in the language of the migrants' country of origin. The fieldwork lasted from November 2010 until June 2011. In January 2011, CBS supplied new addresses of migrants who came to the Netherlands in the period from September-December 2010. The number of verified incorrect addresses was quite high among Poles and Bulgarians (32\% and 37\%, respectively). Moreover, at addresses where interviewers had found no one at home on six occasions, it is possible that the migrant was no longer living there as well.

A total of 874 interviews were completed among Polish migrants and 456 among migrants from Bulgaria. Based on the gross sample, a response rate of $35 \%$ was achieved among Polish migrants. Leaving out the addresses which proved to be incorrect, the response rate rose to $52 \%$. The comparable percentages for the Bulgarian migrants were $29 \%$ and $46 \%$. A comparison with population statistics of these two groups of recent immigrants provided by Statistics Netherlands showed that men were slightly underrepresented in the sample, while the data on age proved to be representative. Migrants from the four largest municipalities in the west of the Netherlands (Amsterdam, Rotterdam, The Hague and Utrecht) were overrepresented relative to the sample frame. Descriptive statistics are weighted by sex, age and region.

Drawing the sample from the Municipal Personal Records Database (GBA) naturally meant that migrants who were not entered in the Database were not reached. It is likely that these would in the main be short-term migrants from Poland and Bulgaria who were in the Netherlands only temporarily for work (e.g. as seasonal workers). If migrants are in (temporary) paid employment in the Netherlands, they are entered in the employees' register (and given a tax and social insurance number), but often do not appear in the population register (GBA), in which they are only required to register if 
they intend spending longer than four months in the Netherlands. The SCIP survey focuses on integration processes, with the expectation that migrants who have themselves entered in the GBA are probably intending to stay longer in the Netherlands. Migrants who do not register immediately after their arrival in the Netherlands but who do so later are recorded as new migrants at that time. It therefore regularly occurred in interviews that the migration date stated by the migrant was earlier than the formal registration date held by CBS. This applied to a lesser extent for Bulgarians than for Poles. This was a major reason for controlling for the length of time that migrants had spent in the Netherlands in our study. There is of course a selection effect here, as Poles and Bulgarians who had removed their names from the register (or who had never registered) and had remigrated might have been less successful on the Dutch labour market. If failing to get a job is a reason for removing oneself from the GBA register, a logical consequence is that length of stay has a strong effect on having a job for Poles and Bulgarians.

We restricted the group for analysis to Poles and Bulgarians who reported that they had resided in the Netherlands for less than four years. Those who had been in the Netherlands for longer - 123 Poles (14.1\%) and 49 Bulgarians (10.7\%) - were excluded because we no longer regarded them as recent migrants. We then selected only those recent migrants who had come to the Netherlands for economic or family reasons, because our hypotheses focused on these forms of migration. Migrants who reported that they had come to the Netherlands to study or for other reasons not stated here were excluded (92 Poles and 90 Bulgarians).

\section{Measurement instruments}

\section{Dependent variables}

Respondents were asked what their main activity was in the country of origin just before migrating to the Netherlands and what their day-to-day activity was in the Netherlands at the time of the interview. From this we constructed the variables indicating whether people were working in the country of origin and whether they were working in the Netherlands. The 13 Bulgarians and three Poles who did not answer this question were excluded. If respondents answered that they were working, they were asked to describe their job, both in the country of origin and in the Netherlands. Respondents without a job were asked whether they had had a job during the period that they had been in the Netherlands or whether they had had a job in their country of origin, and they were then asked to describe the last job they had held. The ISCO-2008 job classification system was used for the coding of the jobs, following which the jobs were classified by occupational status (ISEI; Den Boer, 2011) based on a coding scheme developed by Ganzeboom (2010). Of the respondents who had had a job in their country of origin, 30 gave responses that could not be coded; 42 respondents who held or had held a job in the Netherlands also gave uncodifiable responses; these respondents were left out of the occupational status analysis. The jobs from the country of origin and in the Netherlands were translated into Dutch, and for each migrant the pre- and post-migration jobs were coded by the same coder. For the limited descriptions of jobs (e.g. manual worker, construction worker, warehouse worker, picker) a coding guideline was used.

Finally, respondents were asked how satisfied they were with the income from their job in the Netherlands (five response categories, ranging from very dissatisfied to very 
satisfied). This question was only put to migrants who were in work at the time of the interview (unlike occupational status, these were thus not respondents who were currently not working but who had had a job in the Netherlands). Since the category 'very dissatisfied' hardly occurred, it was merged with the category 'dissatisfied'. These respondents with work in the Netherlands were also asked about their satisfaction with their income in the country of origin, if they had had worked there. The same coding system was applied for satisfaction with income from employment in the country of origin.

\section{Independent variables}

Origin Migrants were classified by origin based on their country of birth. The migrants in the study were born in either Poland or Bulgaria. We also controlled for whether a respondent belonged to the Turkish minority in Bulgaria. In a previous publication it was shown that a large part of the migrants from Bulgaria belong to the Turkish minority in Bulgaria. This group has a history of suppression and discrimination in Bulgaria itself (Petkova, 2002). The Turkish Bulgarian migrants turned out to be very low educated (see Gijsberts \& Lubbers, 2013).

Migration motive Respondents were asked about their motives for migration. Several responses were possible, though in practice most respondents gave only one. For this study we selected only migrants who reported economic and family-related motives. If respondents cited both economic and family-related motives (39 occasions), they were classified as 'family-related motives'.

Intention to stay in the Netherlands Respondents were asked whether they expected to stay in the Netherlands, to move back and forth between the country of origin and the Netherlands, whether they thought to return to country of origin or move to another country. Respondent intended to stay longer in the Netherlands were coded 1, whereas all the other respondents were coded 0 .

We followed Chiswick et al. (2005) by controlling not only for migrants' age and gender but also for the number of months that the migrant had spent in the Netherlands, whether the respondent had a working partner and whether there were children under five years old living in the household. We also included educational level. An education classification system that was specific to the country of origin was applied for each migrant group. The highest level of education attained was coded as low, lower secondary, upper secondary or higher education, based on the ISCED classification system. If a respondent had followed a higher level of education in the Netherlands (e.g. a Master's programme), this higher education level was assigned to that respondent. Although this may seem strange because studymigrants were consciously eliminated from our selection process, migrants who indicated that they had not come to the Netherlands to study (but to find work or for family reasons or both) may still have decided to follow a course of study in the Netherlands. In the event, however, only nine Polish and Bulgarian respondents who had come to the Netherlands for economic or family motives reported that they had completed a study in the Netherlands. We also controlled for whether migrants had made efforts to learn Dutch before migration and whether they spoke English. Unfortunately, information on labour market experience and possession of a work permit are lacking in the data. The number of migrants with a 
missing value for one of the independent variables (after selections on the dependent variables) was excluded from the analysis (24 Poles and 7 Bulgarians).

The descriptive statistics in Table 1 show that the proportion of family migrants among the 635 Poles and 298 Bulgarians is small in comparison with the proportion of labour migrants. For every family migrant from Poland, there are six labour migrants, and there are three labour migrants for every family migrant from Bulgaria. Bulgarian migrants have more often spent a short period (less than a year) in the Netherlands than Poles. Bulgarian migrants are also less well educated on average and speak English considerably less often than Polish migrants. Both Poles and Bulgarians made virtually no effort to learn the Dutch language before coming to the Netherlands. Poles have a working partner in the Netherlands more often than Bulgarians, and also more often have a young child in the household.

Table 1 Descriptive statistics broken down for Poles and Bulgarians (weighted by sex, age and region)

\begin{tabular}{|c|c|c|c|}
\hline & Min-max & $\begin{array}{l}\text { Poles } \\
(n=635)\end{array}$ & $\begin{array}{l}\text { Bulgarians } \\
(n=298)\end{array}$ \\
\hline Work in the Netherlands & $0-1$ & $82.6 \%$ & $47.4 \%$ \\
\hline \multicolumn{4}{|l|}{ Situation in country of origin } \\
\hline - Unemployed (ref.) & $0-1$ & $10.8 \%$ & $48.1 \%$ \\
\hline - In work & $0-1$ & $73.9 \%$ & $30.7 \%$ \\
\hline - At school & $0-1$ & $12.3 \%$ & $10.8 \%$ \\
\hline - Other & $0-1$ & $3.0 \%$ & $10.4 \%$ \\
\hline \multicolumn{4}{|l|}{ Migration motive } \\
\hline - Family (ref.) & $0-1$ & $14.5 \%$ & $25.0 \%$ \\
\hline - Work & $0-1$ & $85.5 \%$ & $75.0 \%$ \\
\hline Intention to stay in the Netherlands & $0-1$ & $48.7 \%$ & $28.9 \%$ \\
\hline Education level & $1-4$ & 2.8 & 2.1 \\
\hline Command of English & $0-1$ & $53.5 \%$ & $19.5 \%$ \\
\hline Attempt to learn Dutch before migration & $0-1$ & $7.4 \%$ & $2.8 \%$ \\
\hline \multicolumn{4}{|l|}{ Number of months in NL } \\
\hline$-<12$ months & $0-1$ & $28.5 \%$ & $66.6 \%$ \\
\hline - 12-24 months & $0-1$ & $23.9 \%$ & $25.1 \%$ \\
\hline - 24-48 months & $0-1$ & $42.2 \%$ & $8.1 \%$ \\
\hline - missing & $0-1$ & $5.4 \%$ & $0.2 \%$ \\
\hline Partner with work & $0-1$ & $56.2 \%$ & $33.0 \%$ \\
\hline Child younger than 5 in household & $0-1$ & $15.2 \%$ & $7.9 \%$ \\
\hline Man & $0-1$ & $52.2 \%$ & $48.8 \%$ \\
\hline Age & $18-62$ & 31.9 & 31.4 \\
\hline \multirow[t]{2}{*}{ Turkish Bulgarian minority } & $0-1$ & - & $60.8 \%$ \\
\hline & & $(n=499)$ & $(n=75)$ \\
\hline Occupational status in Netherlands - ISEI & $15-77$ & 29.0 & 28.7 \\
\hline \multirow[t]{2}{*}{ Occupational status in country of origin - ISEI } & $10-75$ & 36.4 & 32.3 \\
\hline & & $(n=450)$ & $(n=71)$ \\
\hline Satisfaction with income in Netherlands & $1-4$ & 2.8 & 2.9 \\
\hline Satisfaction with income in country of origin & $1-4$ & 1.8 & 2.1 \\
\hline
\end{tabular}

Source: SCIP, the Netherlands wave 1, 2011 


\section{Results}

Paid work

$83 \%$ of the Polish migrants succeed in finding work in the Netherlands. In stark contrast, $47 \%$ of Bulgarian migrants who came to the Netherlands for reasons other than study report to be in work after their migration to the Netherlands. If we compare the situation after migration with the labour participation rate before migration, we find that $74 \%$ of the same group of Polish migrants had work in Poland, and that 31\% of the Bulgarian migrants had work in Bulgaria. It should be noted here that over 10\% of the Poles and Bulgarians who report work or family reasons as the main migration motive were still in education just before migrating. For both groups, we find an increase in the chance of work when comparing the situation before and after migration. This is in line with the general expectations from the migration labour market literature, with the caveat that a proportion of the migrants were not working in their country of origin because they were in education. Although the percentage in work is substantially lower in the Bulgarian group, we do observe a stronger increase in this group when comparing the situations before and after migration, which we did not anticipate. Expressed as the odds ratio for having a job versus not having a job in the Netherlands compared with having a job versus not having a job in the country of origin, we find an odds ratio of 1.7 for Polish migrants and 2.0 for the Bulgarians. Poles so often already had a job in Poland, that labour market participation almost reached its ceiling.

In Table 2, it is shown that the lower labour market participation among the Bulgarians (both for ethnic Bulgarians and Turkish Bulgarians) as compared to the Poles remains once controlled for their labour market position in the country of origin and other relevant characteristics. For Poles and Bulgarians, we find that work-related migration leads to a higher chance of finding work than family-related migration (see Table 2). ${ }^{1}$ This appears to be a trivial finding, but even among migrants who migrated for work reasons, a high proportion of Bulgarians report that they do not have a job in the Netherlands, or were not willing to tell that they have an informal job.

It is interesting to see that the chance of finding work in the Netherlands is not lower for the Poles and Bulgarians who were unemployed prior to migration compared with those who had a job pre-migration. Moreover, the interactions show that there is no difference between Poles and Bulgarians on this point. The group that has been in the Netherlands the longest has a greater chance of being in work; this is a significant though not very strong effect. The selection effect appears to play a role here, with the associated hypothesis that unemployment leads to a higher chance of remigration. For the other characteristics, we find that men have a job post-migration significantly more often than women, regardless of their labour market situation in the country of origin and their migration motive. The presence of a child younger than five in household reduces the chance of being in work.

\section{Socioeconomic occupational status}

The occupational status in their country of origin of migrants who were in work both before and after migration was 36 for Poles and 32 for Bulgarians. In both migrant groups, their occupational status after migration was lower on average than before migration: 29 in both groups (see Fig. 2). The general decline in occupational status among migrants just after migration is in line with 
Table 2 Logistic regression of having versus not having a job in the Netherlands immediately after migration (excluding migrants with a migration motive other than work or family) $(n=933)$

\begin{tabular}{|c|c|c|}
\hline & $\mathrm{B}$ & $\mathrm{OR}$ \\
\hline \multicolumn{3}{|l|}{ Ethnic group } \\
\hline \multicolumn{3}{|l|}{ - Poles (ref.) } \\
\hline - Ethnic Bulgarians & $-1.99 * * *$ & 0.14 \\
\hline - Turkish Bulgarians & $-1.87^{* * *}$ & 0.16 \\
\hline \multicolumn{3}{|l|}{ Situation in country of origin } \\
\hline \multicolumn{3}{|l|}{ - Unemployed (ref.) } \\
\hline - Employed & -0.16 & 0.85 \\
\hline - At school & 0.04 & 1.04 \\
\hline - Other & -0.58 & 0.56 \\
\hline \multicolumn{3}{|l|}{ Interaction migrant group * situation country of origin } \\
\hline - Bulgarians * Work in country of origin & 0.37 & \\
\hline - Bulgarians * At school in country of origin & $-1.21 \sim$ & \\
\hline - Bulgarians $*$ Other situation in country of origin & 0.53 & \\
\hline \multicolumn{3}{|l|}{ Migration motive } \\
\hline \multicolumn{3}{|l|}{ - Family (ref.) } \\
\hline - Work & $1.22^{* * *}$ & 3.39 \\
\hline Intention to stay in the Netherlands & -0.03 & 0.97 \\
\hline Education level & -0.14 & 0.87 \\
\hline Command of English & 0.04 & 1.04 \\
\hline Attempt to learn Dutch before migration & -0.18 & 0.83 \\
\hline \multicolumn{3}{|l|}{ Number of months in Netherlands } \\
\hline \multicolumn{3}{|l|}{ - <12 months (ref.) } \\
\hline - 12-24 months & 0.15 & 1.17 \\
\hline - 24-48 months & $0.46^{*}$ & 1.59 \\
\hline - missing & -0.11 & 0.89 \\
\hline Partner with work & 0.04 & 1.03 \\
\hline Child aged under five in household & $-0.88^{* * *}$ & 0.42 \\
\hline Man & $1.15^{* * *}$ & 3.15 \\
\hline Age & -0.00 & 1.00 \\
\hline Intercept & 0.73 & \\
\hline Nagelkerke $\mathrm{R}^{2}$ & 0.37 & \\
\hline
\end{tabular}

Source: SCIP, the Netherlands, wave 1, 2011

$\mathrm{B}=$ Logit; $\mathrm{OR}=$ Odds Ratio

${ }_{* * *}=p<0.001 ;{ }^{*}=p<0.05 ; \sim=p<0.10$

the idea of the U-shaped occupational status mobility curve as described by Chiswick et al. (2005).

Our model for analysing changes in occupational status uses the same characteristics as Chiswick et al. (2005). In the model in which change in occupational status is the dependent variable, those authors also used occupational status in the country of origin (in quartiles) as a predictor. They also analysed the occupational status immediately postmigration and regressed it to the same characteristics. We show the results of those analyses as well, with in Table 3 the findings from the model with the change scores as dependent variable and in Appendix 1 the post-migration occupational status, regressing both on pre-migration occupational status, implying mathematically comparable models. 


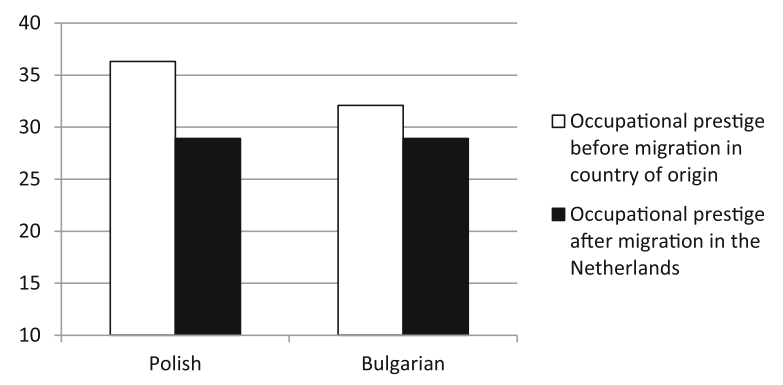

Fig. 2 Occupational status before and after migration on the ISEI-ladder (minimum 10; maximum 90) of migrants who had a job both in the country of origin and in the Netherlands, by ethnic origin, 2011 (weighted averages)

We note that the number of Bulgarians is small in this analyses $(n=75)$ because only a small proportion within this group had a job both in the country of origin and in the Netherlands (25\% of the migrants studied). This percentage is much higher among the Poles $(79 \% ; n=499)$. Bulgarians were often unemployed in Bulgaria, implying that for those with a job in the Netherlands we cannot make a comparison in occupational status.

Table 3 Regression analysis of change in occupational status comparing post-migration with pre-migration status among recent Polish and Bulgarian migrants (non-standardised coefficients $)(N=574)$

\begin{tabular}{lll}
\hline & $b$ & Beta \\
\hline Ethnic group & & \\
- Poles (ref.) & & 0.04 \\
- Ethnic Bulgarians & 2.28 & -0.01 \\
- Turkish Bulgarians & -0.35 & -0.71 \\
Occupational status in country of origin & $-0.84^{* * *}$ & \\
Migration motive & & -0.06 \\
- Family (ref.) & & -0.03 \\
- Work & $-2.92^{*}$ & 0.09 \\
Intention to stay in the Netherlands & -0.72 & 0.06 \\
Education level & $1.59^{*}$ & 0.06 \\
Command of English & 1.75 & \\
Attempt to learn Dutch before migration & $3.23 \sim$ & -0.01 \\
Number of months in Netherlands & & 0.25 \\
- <12 months (ref.) & & 0.02 \\
- 12-24 months & & -0.06 \\
- 24-48 months & $-2.00 \sim$ & 0.03 \\
- missing & -1.44 & -0.05 \\
Partner with work & 3.28 & -1.36 \\
Child aged under five in household & -0.28 & \\
Man & $7.41^{* * *}$ & 0.03 \\
Age & 16.52 & \\
\hline
\end{tabular}

Source: SCIP, the Netherlands, wave 1, 2011

$\mathrm{b}=$ unstandardized regression coefficient; Beta $=$ standardized regression coefficient

${ }^{* * *}=p<0.001 ;{ }^{*}=p<0.05 ; \sim=p<0.10$ 
Moreover, as we found earlier, they often indicate to be unemployed in the Netherlands as well, corresponding to a weaker position at the time of our research, where the requisition of a work permit may have contributed in searching for jobs in the informal labour market.

Bulgarians who worked in Bulgaria do not underperform Poles post-migration status after controlling for the other characteristics and for their socioeconomic occupational status in the country of origin. The effect parameter is positive but not significant. This finding runs counter to the differences we formulated between Bulgarians and Poles. Since jobs in the informal labour market generally have lower status, it is likely that the post-migration job status among the Bulgarians is overestimated.

Also contrasting to our expectations is that migrants with longer stay perspective in the Netherlands did not witness less downgrading in occupational status. Intention to stay is not significantly related to change in occupational status. Although we found that labour migrants have a better chance of having a job after migration than family migrants, we show that labour migrants lose more occupational status after migration than family migrants who are in work, which is in line with previous U-curve expectation findings. The effect parameter of -2.92 (see Table 3 ) indicates that the occupational status of migrants with economic motives is almost 3 points lower than that of migrants with family-related motives after controlling for occupational status in the country of origin.

Among the other characteristics, gender has a strong effect; not only do men have a greater chance of having a job after migration than women, they also have a higher socioeconomic occupational status than women. The occupational status of women postmigration falls more sharply than that of men. Also interesting is the weak negative effect of the number of months (between 12 and 24) that migrants have been in the Netherlands. Although we focused mainly on the downward movement in the first part of the U-curve, this negative effect appears to suggest that these migrants did not experience an upward trend in status during the period covered by our study that they were in the Netherlands. Educational level is found to have a positive influence (see Table 3). The general decline in occupational status among migrants is less marked for highly skilled migrants. The same applies for (the few) migrants who invested in learning Dutch before their migration.

The occupational status in the country of origin is a significant predictor for the current occupational prestige in both groups (see Appendix 1). If occupational status in the country of origin were a perfect predictor of occupational status in the Netherlands, the regression coefficient would be 1 . In practice, the coefficient in the Polish group is estimated at 0.16, and for the Bulgarians at 0.12 (no significant difference). Occupational status in the country of origin is therefore a moderate predictor of occupational status in the Netherlands.

\section{Satisfaction with income}

Finally, we looked at the satisfaction with income from employment. Figure 3 shows that the level of satisfaction is considerably higher in the Netherlands than in the country of origin. Poles in particular were dissatisfied with their income from employment in the country of origin. Poles are slightly more often dissatisfied than Bulgarians with their income in the Netherlands, but the differences are not large.

Table 4 shows that satisfaction with income in the country of origin is a poor predictor of income satisfaction in the Netherlands for both Poles and Bulgarians. The 

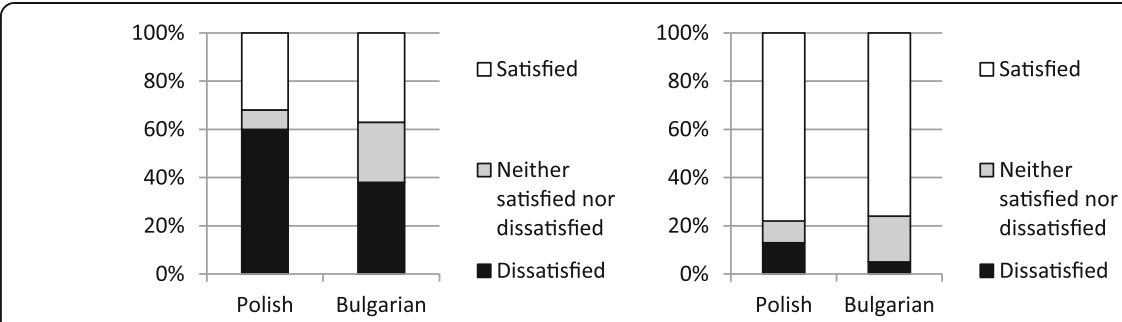

Fig. 3 Satisfaction with income from employment in the country of origin (left-hand figure) and income from employment in the Netherlands (right-hand figure), 2011 (weighted averages)

differences between Poles and Bulgarians are moreover not significant, which means we have to reject our hypothesis that Bulgarians experience a greater increase in satisfaction with income than Poles. ${ }^{2}$ In fact we find that the characteristics in our model explain hardly variance in income satisfaction. The only convincing predictor in our model for income satisfaction is the occupational status of the present occupation.

Table 4 Regression analysis of satisfaction with income from employment immediately after migration, recent Polish and Bulgarian migrants $(N=496)$

\begin{tabular}{lll}
\hline & $b$ & Beta \\
\hline Ethnic group & 0.22 & 0.71 \\
- Poles (ref.) & & \\
- Ethnic Bulgarians & 0.09 & 0.02 \\
- Turkish Bulgarians & 0.00 & 0.00 \\
Income satisfaction in country of origin & 0.02 & 0.02 \\
Interaction Migrant group * Income satisfaction in country of origin & 0.04 & \\
Migration motive & & -0.02 \\
- Family (ref.) & & -0.12 \\
- Work & -0.05 & 0.15 \\
Intention to stay in the Netherlands & $-0.20^{*}$ & 0.03 \\
Occupational status in the Netherlands & $0.01^{* *}$ & 0.10 \\
Education level & 0.04 & 0.02 \\
Command of English & $0.18 \sim$ \\
Attempt to learn Dutch before migration & 0.09 & -0.04 \\
Number of months in Netherlands & & 0.02 \\
- <12 months (ref.) & & 0.03 \\
- 12-24 months & & 0.04 \\
- 24-48 months & & \\
- missing & 0.13 & 0.09 \\
Partner with work & 0.10 & 0.06 \\
Child aged under five in household & $-0.66^{*}$ & 0.07 \\
Agan & 0.05 & 0.00 \\
\hline Adjusted R & 0.13 & \\
\hline
\end{tabular}

Source: SCIP, the Netherlands, wave 1, 2011

$\mathrm{b}=$ unstandardized regression coefficient; Beta $=$ standardized regression coefficient

${ }^{* *}=p<0.01 ;{ }^{*}=p<0.05 ; \sim=p<0.10$ 


\section{Conclusions}

Polish and Bulgarian migrants have been free to move to the Netherlands since 2004 and 2007 respectively. At the time of our study (2010/2011), Bulgarians were still in need of a work permit to obtain a job on the Dutch labour market. Despite these specific circumstances that are quite different than the strong migration regulations that apply for migrants to Anglo-Saxon countries, this study shows that Polish and Bulgarian migrants to the Netherlands have a lower occupational status shortly after migration than before migration, a finding that is in line with the international literature.

Polish migrants have jobs after migration more often than they did in Poland, but that is mainly because a proportion of them were still at school before migration. The vast majority of the other Polish migrants had work in Poland before migrating. Bulgarians have a job after migrating more often than before migrating, although the proportion with a job is still very low (approximately half). Why the Bulgarians have a so much lower labour market participation remains unclear. However, an overview of the occupations in which the Bulgarians work, mainly in cleaning, construction and food and beverage sector, suggests that informal work is common. Engbersen et al. (2011) showed that many Bulgarians in their study had informal contracts. It might have been the case that Bulgarians working in the informal sector were not willing to give information on them holding this job position. If this indeed is the case, then the occupational status of Bulgarians is probably overestimated, and will the decline in status for the Bulgarians have been more sharply. Yet the labour market position of Bulgarians in the Netherlands can be described as worrying because a high proportion of even those migrants who came in order to work report that they do not have a job in the Netherlands. Work permits were introduced in order to regulate the influx of migrants from the new accession countries. The measure does not appear to have constrained migration by Bulgarians without work, however; even worse, it poses a serious obstacle for jobless Bulgarians in the Netherlands to finding (formal) employment. A multi-migrant group to more destination countries perspective should provide more insight in the consequences of these specific labour market regulations. Based on our findings, we anticipate that the scrapping of the work permit in January 2014 will have contributed to the labour market integration of Bulgarians in the Netherlands, by increasing their (formal) labour participation rate.

Our study was conducted among migrants in 2010 and 2011, and who had been in the Netherlands for a relatively short time. Earlier research (Akresh, 2006; 2008; Chiswick et al., 2005; Simon et al., 2011) has shown that migrants experience a marked U-curve in their occupational status. The first part of the U-curve is clearly evident in our study, but primarily for labour migrants, who are expected to take on a job earlier and have less information channels than family motivated migrants. We find no confirmation in our study that migrants with shorter intentions to stay faced a sharper decrease in occupational status as well.

We did not find the upward movement in the U-curve among the migrants studied here. We found no positive effect of duration of residence in the Netherlands on socioeconomic job status. The literature is not very specific about the period over which the upward movement in the U-curve supposedly occurs. It may be relevant here to look in succession at the different jobs that migrants have after migration. However, 
one difficulty here is the fact that labour migrants often have a number of (small) jobs alongside and after each other. For the time being, we conclude that (a maximum of) four years in the Netherlands is insufficient for Polish and Bulgarian migrants to achieve an increase in their socioeconomic position. An earlier study by Van Tubergen (2005) showed that an increase in occupational status was seen only after a period of residence of more than ten years in the host country. However, it may be that this upward movement of the U-curve can also be explained by selective remigration of migrants who - in terms of occupational status - are less successful. Moreover, recent studies have come to question whether after an initial decline it is still realistic on the dynamic $21^{\text {st }}$ century labour market to anticipate an upward trend (Alba \& Foner, 2015). Pereira, Snel, and 't Hart (2015) found recently that non-EU migrants were unable to improve their occupational position in the longer run.

Both groups of recent migrants are more satisfied with their income from employment in the Netherlands than in their country of origin. Although we did not study the actual change in income, we can deduct from these findings that improvement in income appears to be a major driver for migration by Poles, for which they are prepared to accept a lower occupational status in the Netherlands. This also applies for the Bulgarians, but for them having a job at all in which they can earn money seems an important motive.

Our study was limited to migrants who registered in the population register. Migrants to the Netherlands are expected to do so when they stay for more than four months, and since 2014, also temporary migrants who need a personal taxation number are expected to register. We anticipate that the temporary workers or seasonal workers are more likely to pick up flexible low-skilled jobs, e.g. assistants in construction work or as agricultural workers. The selection of migrants in certain occupations into the registration will likely affect our findings. It is expected that inclusion of migrants who did not register and worked in temporary jobs would have lowered occupational status post-migration. Whether the decline of occupational status would have been affected depends on whether temporary migrants form a selection in job position in the country of origin.

Compared to previous research in which migrants under different migration regulations moved to their host country, the findings are markedly similar regarding loss in occupation status. Following the recent contributions from Pereira et al. (2015)) and Alba and Foner (2015), the interesting question is whether the intra-EU migrants from Eastern Europe manage to follow the U-curve upwards with longer stay or whether their migration experience provides benefits in finding a higher status job in their country of origin or elsewhere.

\section{Endnotes}

${ }^{1}$ In a model which classified migrants who cited both family and work as motives for migration as labour migrants, the positive effect is even stronger.

${ }^{2}$ An analysis taking the difference between income satisfaction in the Netherlands and in the country of origin as dependent variable also reveals no significant difference between Bulgarians and Poles. 


\section{Appendix 1}

Table 5 Regression analysis of occupational status after migration among recent Polish and Bulgarian migrants (non-standardised coefficients) $(N=574)$

\begin{tabular}{|c|c|c|}
\hline & $\mathrm{b}$ & Beta \\
\hline \multicolumn{3}{|l|}{ Ethnic group } \\
\hline \multicolumn{3}{|l|}{ - Poles (ref.) } \\
\hline - Ethnic Bulgarians & 3.72 & 0.08 \\
\hline - Turkish Bulgarians & 0.80 & 0.02 \\
\hline Occupational status in country of origin & $0.16^{* * *}$ & 0.18 \\
\hline Interaction Migrant group * Occupational status in country of origin & -0.04 & \\
\hline \multicolumn{3}{|l|}{ Migration motive } \\
\hline \multicolumn{3}{|l|}{ - Family (ref.) } \\
\hline - Work & $-2.95^{*}$ & -0.08 \\
\hline Intention to stay in the Netherlands & -0.74 & -0.03 \\
\hline Education level & $1.60^{* *}$ & 0.11 \\
\hline Command of English & 1.75 & 0.08 \\
\hline Attempt to learn Dutch before migration & 3.20 & 0.07 \\
\hline \multicolumn{3}{|l|}{ Number of months in Netherlands } \\
\hline \multicolumn{3}{|l|}{ - $<12$ months (ref.) } \\
\hline - 12-24 months & $-1.98 \sim$ & -0.07 \\
\hline - 24-48 months & -1.41 & -0.06 \\
\hline - missing & 3.30 & 0.04 \\
\hline Partner with work & -1.34 & -0.06 \\
\hline Child aged under five in household & -0.28 & -0.01 \\
\hline Man & $7.45^{* * *}$ & 0.33 \\
\hline Age & 0.03 & 0.03 \\
\hline Intercept & 16.31 & \\
\hline$R^{2}$ & 0.21 & \\
\hline
\end{tabular}

Source: SCIP, the Netherlands, wave 1, 2011

$\mathrm{b}=$ unstandardized regression coefficient; Beta $=$ standardized regression coefficient

${ }^{* * *}=p<0.001 ;{ }^{* *}=p<0.01 ;{ }^{*}=p<0.05 ; \sim=p<0.10$

\section{Authors' contributions}

Both authors drafted the manuscript and both authors contributed to build the syntax for analyses. The first author has performed the final analyses. Both authors participated in writing of the article. All authors read and approved the final manuscript.

\section{Competing interests}

The authors declare that they have no competing interests.

\section{Author details}

${ }^{1}$ Department of Sociology, Radboud University Nijmegen, 6500 HE Nijmegen, The Netherlands. ${ }^{2}$ Department of Cultural Diversity and Youth, Utrecht University, 3584 CS Utrecht, The Netherlands.

Received: 2 April 2016 Accepted: 19 November 2016

Published online: 16 December 2016

\section{References}

Akresh, I. R. (2006). Occupational mobility among legal immigrants to the United States. International Migration Review, $40,854-884$.

Akresh, I. R. (2008). Occupational trajectories of legal US immigrants: downgrading and recovery. Population and Development Review, 34, 435-456. 
Alba, R. \& Foner, N. (2015). Strangers no more: Immigration and the challenges of integration in North America and Western Europe. Princeton: Princeton University Press

Amuedo-Dorantes, C., \& De la Rica, S. (2006). Labor market integration of recent immigrants in Spain (IZA Discussion Paper No. 2014). Bonn: IZA.

Baker, M., \& Benjamin, D. (1994). The performance of immigrants in the Canadian labor market. Journal of Labor Economics, 12, 369-405.

Barrett, A., \& Duffy, D. (2008). Are Ireland's immigrants integrating into its labor market? International Migration Review, 42, 597-619.

Bauer, T. K., \& Zimmermann, K. F. (1999). Occupational mobility of ethnic migrants (No. 58). IZA Discussion paper series. Borjas, G. J. (1989). Economic theory and international migration. International Migration Review, 23, 457-485.

Castles, S., \& Miller, M. J. (2003). The Age of Migration. International Population Movements in the Modern World (3rd ed.). Houndmills: Palgrave MacMillan.

Chiswick, B. R., Lee, Y. L., \& Miller, P. W. (2005). A longitudinal analysis of immigrant occupational mobility: A test of the immigrant assimilation hypothesis. International Migration Review, 39, 332-353.

Den Boer, P. (2011). Tijdreeksen werkzame beroepsbevolking naar beroepsprestige, sociaal-economische status en sociale klasse. Den Haag: Centraal Bureau voor de Statistiek.

Diehl, C., Gijsberts, M., Güveli, A., Koenig, M., Kristen, C., Lubbers, M., . . \& Van Tubergen, F. (2015). Socio-Cultural Integration Processes of New Immigrants in Europe (SCIP) - Data file for download. Cologne: GESIS Data Archive. ZA5956 Data file

Engbersen, G., llies, M., Leerkes, A. S., Snel, E., \& Van der Mei, R. (2011). Arbeidsmigratie in vieren. Bulgaren en Roemenen vergeleken met Polen. Rotterdam: Erasmus Universiteit Rotterdam (Afdeling Sociologie).

Engbersen, G., Leerkes, A., Grabowska-Lusinska, I., Snel, E., \& Burgers, J. (2013). On the differential attachments of migrants from Central and Eastern Europe: A typology of labour migration. Journal of Ethnic and Migration Studies, 39(6), 959-981.

Eurostat (2013a). National accounts (including GDP) and Unemployment rates by sex and age groups - annual average in percentages. Retrieved 21 January 2013 from appsso.eurostat.ec.europa.eu

Eurostat (2013b). Mean and median income by most frequent activity status. Retrieved 21 January 2013 from appsso. eurostat.ec.europa.eu

Fuller, S., \& Martin, T. F. (2012). Predicting immigrant employment sequence in the first years of settlement. International Migration Review, 46(1), 138-190.

Ganzeboom, H. (2010). Recoding Scheme from ISCO08 to ISEI08. Retrieved from: http://home.fsw.vu.nl/hbg.ganzeboom/ ismf/.\%5Cisco08\%5Cindex.htm.

Gijsberts, M., \& Lubbers, M. (2013). Nieuw in Nederland. Het leven van Bulgaren en Polen in Nederland [New in the Netherlands. The living situation of Bulgarians and Poles in the Netherlands]. Den Haag: Sociaal en Cultureel Planbureau.

Gresser, A., \& Schacht, D. (2015). SCIP Survey Methodological Report. GESIS-Sowiport (URL: http://sowiport.gesis.org/ search/id/gesis-sofis-00114139/Description\#tabnav).

Kennan, J., \& Walker, J. R. (2011). The effect of expected income on migration decisions. Econometrica, 1, 211-251.

Mahuteau, S., \& Junankar, P. N. (2008). Do migrants get good jobs in Australia? The role of ethnic networks in job search. The Economic Record, 84, 115-130.

Pereira, S., Snel, E., \& 't Hart, M. (2015). Economic progress, stagnation or decline? Occupational moblity of non-EU immigrants in Europe. In J. Vellejo (Ed.), Research in the Sociology of Work. Volume 127: Immigration and Work (pp. 129-164). Bingle: Emerald.

Petkova, L. (2002). The ethnic Turks in Bulgaria: social integration and impact on Bulgarian-Turkish relations, 1947-2000. The Global Review of Ethnopolitics, 1(4), 42-59.

Rijksoverheid (2013). Tewerkstellingsvergunning voor buitenlandse werknemers WWork permit for foreign employees]. http://www.rijksoverheid.nl/onderwerpen/buitenlandse-werknemers-tewerkstellingsvergunningvoor-buitenlandse-werknemers . Retrieved on 28 February, 2013.

Simon, H., Ramos, R., \& Sanroma, E. (2011). Occupational mobility of immigrants in a low skilled economy: The Spanish case (IZA Discussion paper series, No. 5581). Bonn: IZA.

Van der Heijden, P. G. M., Cruyff, M., \& Van Gils, G. (2013). Aantallen geregistreerde en niet-geregistreerde burgers uit MOElanden die in Nederland verblijven [Numbers of registered and non-registered citizens of CEE countries residing in the Netherlands]. Rapportage schattingen 2009 en 2010. Utrecht: Universiteit Utrecht.

Van Tubergen, F. (2005). The Integration of Immigrants in Cross-national Perspective. Origin, Destination and Community Effects. Utrecht: ICS/UU.

Van Tubergen, F. (2006). Occupational status of immigrants in cross-national perspective: a multilevel analysis of 17 Western societies. In T. Smeeding \& G. Parsons (Eds.), Immigration and the Transformation of Europe (pp. 147-171). Cambridge: Cambridge University Press.

\section{Submit your manuscript to a SpringerOpen ${ }^{\circ}$ journal and benefit from:}

- Convenient online submission

- Rigorous peer review

- Immediate publication on acceptance

- Open access: articles freely available online

- High visibility within the field

- Retaining the copyright to your article

Submit your next manuscript at $\boldsymbol{~ s p r i n g e r o p e n . c o m ~}$ 